\title{
PEMBERDAYAAN EKONOMI ANGGOTA KOPERASI JASA KEUANGAN SYARIAH MELALUI PRODUK PEMBIAYAAN DI KOPERASI SIMPAN PINJAM DAN PEMBIAYAAN SYARIAH \\ MUAMALAH BERKAH SEJAHTERA SURABAYA ${ }^{1]}$
}

\author{
Ardian Dwi Bagus S \\ Mahasiswa Program Studi S1 Ekonomi Islam-Fakultas Ekonomi dan Bisnis-Universitas Airlangga
}

Email : ardian.dwi-12@feb.unair.ac.id

Muhammad Nafik HR

Departemen Ekonomi Syariah-Fakultas Ekonomi dan Bisnis-Universitas Airlangga

Email : muhammad.nafik@feb.unair.ac.id

\begin{abstract}
The cooperation of sharia microfinance institutions that have a role and function of the build and develop potential and economic ability members in particular and the society in general to improve the economic and social welfare. The aim of this research is to find out the role of cooperation sharia financial services in economic empowerment of its members. The approach that is used is qualitative approach by case study as a strategy. In the technique of data collection using the techniques of interview directly to the related objects. This research indicated that the cooperative savings and financing sharia convenient Muamalah Berkah Sejahtera Surabaya has a role in the economic empowerment members through financial products by offering the financing products, with various desired model by its members and the most important thing is that these products are using the contract according to the Islamic Law.
\end{abstract}

Keywords: Co-operatives sharia financial services, Economical Empowering, Islamic Saving And Loan And Budgetting Muamalah Berkah Sejahtera.

\section{PENDAHULUAN}

Indonesia memiliki dualisme sistem kevangan yang berbeda yaitu sistem konvensional dan sistem syariah. Koperasi Syariah juga memiliki pengertian yang sama dengan kegiatan usaha yang sama pula (pembiayaan, investasi, dan simpanpinjam) namun berbeda pada pengelolaan dan pembagian hasil usahanya. Pada koperasi konvensional menggunakan sistem bunga, sedangkan pada Koperasi Syariah menggunakan sistem bagi hasil hal ini disesuaikan dengan ajaran agama islam guna menjauhi praktik ribawi.
Dalam Al-Quran telah disebutkan pengharaman atas riba yaitu pada QS. Al-Baqarah: 275.

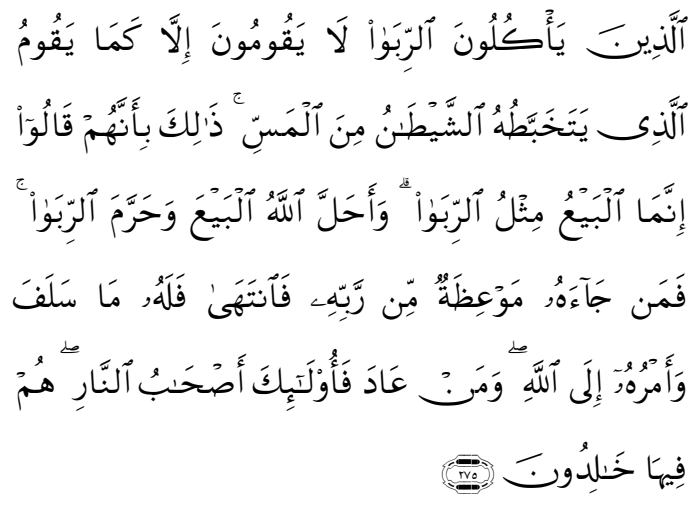

Al-Ladhīna Ya'kulūna Ar-Ribā Lā Yaqūmūna 'Illā Kamā Yaqūmu Al-Ladhī Yatakhabbațuhu Ash-Shayțānu Mina AlMassi Dhālika Bi'annahum Qālū 'InnamāAl-Bay’u Mithlu Ar-Ribā̄ Wa 'Aĥalla Allāhu Al-Bay'a Wa Hiarrama Ar-

'Jurnal ini merupakan bagian dari skripsi dari nama penulis pertama, NIM : 041211431024 yang diuji pada 16 Januari 2017 
Bagus S, et al/Jurnal Ekonomi Syariah Teori dan Terapan Vol. 4 No. 8 Agustus 2017: 657-667; PEMBERDAYAAN EKONOMI ANGGOTA KOPERASI JASA KEUANGAN SYARIAH MELALUI PRODUK PEMBIAYAAN DI KOPERASI SIMPAN PINJAM DAN PEMBIAYAAN SYARIAH MUAMALAH BERKAH SEJAHTERA SURABAYA

Ribā̌Faman Jā'ahu Maw'ižatun Min Rabbihi Fāntahá Falahu Mā Salafa Wa 'Amruhu ' 'lláAllāhī Wa Man 'Āda Fa'ūlā'ika 'Aşhāābu An-Nārr Hum Finā Khālidūn.

Artinya: "Orang-orang yang Makan (mengambil) riba tidak dapat berdiri melainkan seperti berdirinya orang yang kemasukan syaitan lantaran (tekanan) penyakit gila. Keadaan mereka yang demikian itu, adalah disebabkan mereka berkata (berpendapat), Sesungguhnya jual beli itu sama dengan riba, Padahal Allah telah menghalalkan jual beli dan mengharamkan riba. orang-orang yang telah sampai kepadanya larangan dari Tuhannya, lalu terus berhenti (dari mengambil riba), Maka baginya apa yang telah diambilnya dahulu (sebelum datang larangan); dan urusannya (terserah) kepada Allah. orang yang kembali (mengambil riba), Maka orang itu adalah penghuni-penghuni neraka; mereka kekal di dalamnya" (Al-Baqarah :275).

Koperasi Syariah atau yang lebih dikenal dengan Koperasi Jasa Kevangan Syariah (KJKS) memiliki aturan yang relatif sama dengan koperasi umum (konvensional), namun yang membedakannya adalah produkproduk yang ada di koperasi umum diganti dan disesuaikan nama dan sistemnya dengan tuntunan dan ajaran agama islam. Adapun produk koperasi umum jual-beli dan simpan-pinjam yang berganti nama menjadi murabahah dan mudharabah pada Koperasi Jasa Keuangan Syariah. Tidak hanya nama yang berubah namun sistem operasionalnya juga berubah sesuai dengan aturan agama islam.

Koperasi Jasa Keuangan Syariah (KJKS) ini di bentuk dengan tujuan memfokuskan pada produk koperasi di bidang usaha pembiayaan, investasi, dan simpanan. Menurut Peraturan Menteri Negara Koperasi dan Usaha Kecil Dan Menengah Nomor 35.2 /Per/M.KUKM/X/2007 tanggal 5 Oktober 2007 tentang Pedoman Standar Operasional Manajemen Koperasi Jasa Kevangan Syariah dan Unit Jasa Kevangan Syariah Koperasi, Koperasi Jasa Keuangan Syariah (UJKS) adalah unit usaha pada Koperasi yang kegiatan usahanya bergerak di bidang pembiayaan, investasi, dan simpanan sesuai dengan pola bagi hasil (syariah), sebagai bagian dari kegiatan usaha Koperasi yang bersangkutan.

Dari pemaparan terkait koperasi diatas dapat kita ketahui bahwa koperasi memiliki keterkaitan terhadap dua unsur berbeda yaitu unsur ekonomi dan unsur sosial. Sebagai salah satu bentuk dari berbagai bentuk lembaga keuangan yang ada, koperasi seharusnya mengupayakan secara maksimal pada pemenuhan kebutuhan 
Bagus S, et al/Jurnal Ekonomi Syariah Teori dan Terapan Vol. 4 No. 8 Agustus 2017: 657-667; PEMBERDAYAAN EKONOMI ANGGOTA KOPERASI JASA KEUANGAN SYARIAH MELALUI PRODUK PEMBIAYAAN DI KOPERASI SIMPAN PINJAM DAN PEMBIAYAAN SYARIAH MUAMALAH BERKAH SEJAHTERA SURABAYA

ekonomi para anggotanya secara efisien. Sedangkan unsur sosial dapat digambarkan bahwa koperasi merupakan suatu wadah bagi masyarakat untuk berkumpul bersama tanpa menghiraukan berbagai perbedaan pada masing-masing mereka untuk mewujudkan tujuan bersama dari koperasi yaitu mencapai kesejahteraan. Dari sisi lain dapat kita lihat bahwa koperasi memiliki hubungan dengan ekonomi kerakyatan, sebagaimana kita tahu ekonomi kerakyatan dikenal sebagai paham ekonomi yang berpihak pada rakyat (rakyat kalangan menengah kebawah).

Pada kenyataannya terdapat kendala yang cukup serius pada pembangunan masyarakat yaitu permasalahan kemiskinan. Pada dasarnya permasalahan kemiskinan melanda masyarakat atas ketidak berdayaannya dalam mengakses informasi atau kemampuan yang berkaitan dengan aspek ekonomi, sosial serta aspek politik, oleh karenannya pemberdayaan ekonomi masyarakat dinilai sebagai poin utama dalam rangka mengentaskan permasalahan kemiskinan ini. Dalam Kamus Besar Bahasa Indonesia pemberdayaan adalah upaya membuat suatu kemampuan atau berkekuatan, dengan demikian pemberdayaan anggota merupakan upaya untuk memandirikan agar memiliki kemampuan dan kekuatan. Selanjutnya tujuan pemberdayaan menurut Santoso (2008) adalah bekerja bersama masyarakat sehingga masyarakat dapat mendefinisikan dan menangani masalah, dan terbuka untuk mengekspresikan kepentingan mereka sendiri dalam proses pengambilan keputusan.

Bila kita amati keberadaan lembaga keuangan mikro (Koperasi Jasa Keuangan Syariah) merupakan jalan efektif dalam membantu dan memberdayakan anggotanya dan meningkatkan ekonomi keluarga. Hadirnya Koperasi Jasa Keuangan Syariah adalah sebagai sarana yang baik dalam pengentasan kemiskinan yaitu sebagai suatu model penyedia jasa keuangan bagi masyarakat yang masih belum bisa mengakses dunia perbankan karena adanya berbagai macam keterbatasan.

Pada tahun 2008, berawal dari beberapa anggota yang membutuhkan modal usaha, baik dalam bentuk modal inventory ataupun modal vang, maka pengurus berinisiatif untuk memulai pengembangan usaha dibidang simpan pinjam dengan berbasis syariah dan mulai mengakomodir kebutuhan keuangan anggota. Usaha ini pada awalnya hanya dikelola secara sederhana dan 
Bagus S, et al/Jurnal Ekonomi Syariah Teori dan Terapan Vol. 4 No. 8 Agustus 2017: 657-667; PEMBERDAYAAN EKONOMI ANGGOTA KOPERASI JASA KEUANGAN SYARIAH MELALUI PRODUK PEMBIAYAAN DI KOPERASI SIMPAN PINJAM DAN PEMBIAYAAN SYARIAH MUAMALAH BERKAH SEJAHTERA SURABAYA

tanpa pengelolaan khusus, pada tahun 2008 dengan melihat animo anggota pada pada segmen simpan pinjam mulai besar maka ditempatkan satu orang karyawan untuk mengelola secara khusus usaha simpan pinjam. Tahun ini terjadi perubahan penamaan lembaga sesuai surat edaran dari Kementrian Koperasi Dan UMKM menjadi Koperasi simpan pinjam dan pembiayaan syariah (KSPPS) serta terjadi pula sistem pengelolaan mulai mengunakan sistem komputerisasi dan berbagai pengembangan yang terus dilakukan hingga sekarang.

Dari berbagai pemaparan diatas bahwa Koperasi Jasa Keuangan Syariah sebagai salah satu bentuk dari Lembaga Keuangan Mikro yang lebih memfokuskan sasarannya pada pemberdayaan ekonomi anggota dengan tujuan mampu meningkatkan kondisi perekonomiannya. Melihat pada kedekatan konsep Koperasi Jasa Keuangan Syariah (KJKS) dengan pemberdayaan ekonomi maka penulis tertarik untuk mengkaji dan meneliti lebih dalam lagi terkait dengan Koperasi Jasa Keuangan Syariah (KJKS) dan pemberdayaan anggotanya melalui berbagai produk keuangan yang ditawarkan.

\section{II.LANDASAN TEORI}

\section{Koperasi Jasa Kevangan Syariah}

Koperasi Jasa Kevangan Syariah (KJKS) menurut Peraturan Menteri Negara Koperasi dan Usaha Kecil Dan Menengah Nomor $\quad 35.2$ /Per/M.KUKM/X/2007 tanggal 5 Oktober 2007 tentang Pedoman Standar Operasional Manajemen Koperasi Jasa Kevangan Syariah dan Unit Jasa Kevangan Syariah Koperasi, Koperasi Jasa Keuangan Syariah (KJKS) adalah unit usaha pada Koperasi yang kegiatan usahanya bergerak di bidang pembiayaan, investasi, dan simpanan sesuai dengan pola bagi hasil (syariah). Sedangkan jika berbentuk Koperasi Jasa Kevangan Syariah maka didefinisikan sebagai koperasi yang kegiatan usahanya bergerak di bidang pembiayaan, investasi, dan simpanan sesuai pola bagi hasil (syariah).

Prinsip-prinsip Koperasi Jasa Keuangan Syariah

Sebagai salah satu bentuk dari lembaga keuangan syariah Koperasi Jasa Keuangan Syariah memiliki prinsip syariah yang melekat pada setiap lembaga keuangan syariah yang meliputi, prinsip keadilan (justice), prinsip keterbukaan dan kejujuran (transparance and fairness), dan prinsip 
Bagus S, et al/Jurnal Ekonomi Syariah Teori dan Terapan Vol. 4 No. 8 Agustus 2017: 657-667; PEMBERDAYAAN EKONOMI ANGGOTA KOPERASI JASA KEUANGAN SYARIAH MELALUI PRODUK PEMBIAYAAN DI KOPERASI SIMPAN PINJAM DAN PEMBIAYAAN SYARIAH MUAMALAH BERKAH SEJAHTERA SURABAYA

kemitraan (partnership). (Subagyo,

2015:65).

Selain itu Koperasi Jasa Keuangan Syariah merupakan bagian dari Koperasi Syariah sehingga prinsip-prinsip dari Koperasi Syariah juga melekat didalamnya. Adapun prinsip-prinsip Koperasi Syariah yaitu:

a. Prinsip Koperasi Syariah /Unit Jasa Kevangan Syariah dalam prinsip ekonomi islam:

1) Kekayaan adalah amanah Allah SWT. yang tidak dapat dimiliki oleh siapapun secara mutlak.

2) Manusia diberi kebebasan dalam mu'amalah selama tidak melanggar ketentuan syariah.

3) Manusia merupakan wakil Allah dan pemakmur di bumi.

4) Menjunjung tinggi keadilan serta menolak setiap bentuk ribawi dan pemusatan sumber dana ekonomi pada segelintir orang atau sekelompok orang saja. (Solihin, 2010:425).

b. Prinsip Koperasi Syariah /Unit Jasa Keuangan Syariah dalam prinsip syariah islam:

1) Keanggaotaan bersifat sukarela dan terbuka.
2) Keputusan ditetapkan secara musyawarah dan dilaksanakan secara konsisten dan konsekuen.

3) Pengelolaan dilakukan secara transparan dan profesional.

4) Pembagian sisa hasil usaha dilakukan secara adil, sesuai dengan besarnya jasa usaha masing-masing anggota.

5) Pemberian balas jasa modal dilakukan secara terbatas dan profesional menurut sistem bagi hasil.

6) Jujur, amanah, dan mandiri. (Solihin, 2010:426)

Tujuan Koperasi Jasa Keuangan Syariah

Surat Keputusan Menteri Negara Koperasi Dan Usaha Kecil Dan Menengah Tentang Petunjuk Pelaksanaan Kegiatan Usaha Koperasi Jasa Keuangan Syariah menjelaskan tentang produk dan layanan koperasi jasa keuangan syariah/Unit Jasa Kevangan Syariah menjelaskan tentang tujuan pengembangan koperasi jasa keuangan syariah/Unit Jasa Keuangan Syariah tepatnya pada pasal II (tujuan) diantaranya adalah:

a. Meningkatkan program pemberdayaan ekonomi, khususnya di kalangan Usaha 
Bagus S, et al/Jurnal Ekonomi Syariah Teori dan Terapan Vol. 4 No. 8 Agustus 2017: 657-667; PEMBERDAYAAN EKONOMI ANGGOTA KOPERASI JASA KEUANGAN SYARIAH MELALUI PRODUK PEMBIAYAAN DI KOPERASI SIMPAN PINJAM DAN PEMBIAYAAN SYARIAH MUAMALAH BERKAH SEJAHTERA SURABAYA

mikro, kecil menengah dan Koperasi melalui sistem syariah.

b. Mendorong kehidupan ekonomi syariah dalam kegiatan usaha mikro, kecil dan menengah khususnya dan ekonomi Indonesia pada umumnya.

c. Meningkatkan semangat dan peran serta anggota masyarakat dalam kegiatan Koperasi Jasa Kevangan Syariah.

\section{Indikator pemberdayaan ekonomi}

Salah satu indikator telah berdayanya perekonomian adalah terlaksananya kegiatan ekonomi tersebut dengan baik, yaitu meningkatnya produksi serta meningktanya atau terpenuhinya konsumsi dari anggota/masyarakat tersebut. Pengembangan ekonomi dalam islam mengidikasikan bahwa perhatian islam terhadap bidang ekonomi merupakan bagian dari syariah yang menjadi tuntutan dalam upaya pemeliharaan sumber-sumber ekonomi dan pengembangannya, meningkatkan kemampuan produksi dengan mengembangkan sistem dan metodenya, dan hal-hal lain yang menjadi tuntutan dalam merealisasikan kesejahteraan ekonomi umat, memenuhi kebutuhan yang mendasar, dan memerangi kemiskinan (Sholihan, 2006:393).

Menurut Ginandjar Kartasasmita (1996), pemberdayaan ekonomi rakyat adalah Upaya yang merupakan pengerahan sumber daya untuk mengembangkan potensi ekonomi rakyat untuk meningkatkan produktivitas rakyat sehingga, baik sumber daya manusia maupun sumber daya alam di sekitar keberadaan rakyat, dapat ditingkatkan produktivitasnya.

Dengan demikian penulis dapat menyimpulkan bahwa terdapat dua faktor yang dapat dijadikan indikator atau sebagai tolak ukur sebuah perekonomian anggota/masyarakat dikatakan telah berdaya atau tidak, yaitu:
a. Meningkat
atau terpenuhinya konsumsi.
b. Meningkatnya produksi.

\section{METODE PENELITIAN}

\section{Pendeketan penelitian}

Penelitian ini menggunakan pendekatan kuaalitatif. Penelitian ini dilaksanakan dengan harapn mampu menjawab pertanyaann : bagaimana peran produk simpanan dan pembiayaan dalam pemberdayaan ekonomi anggota koperasi jasa kevangan syariah?

Penelitian ini menggunakan strategi studi kasus. Menurut Yin (2013:1) metode studi kasus adalah strategi yang lebih 
Bagus S, et al/Jurnal Ekonomi Syariah Teori dan Terapan Vol. 4 No. 8 Agustus 2017: 657-667; PEMBERDAYAAN EKONOMI ANGGOTA KOPERASI JASA KEUANGAN SYARIAH MELALUI PRODUK PEMBIAYAAN DI KOPERASI SIMPAN PINJAM DAN PEMBIAYAAN SYARIAH MUAMALAH BERKAH SEJAHTERA SURABAYA

cocok bila pokok pertanyaan suatu penelitian berkenaan dengan "how" dan "why", bila peneliti hanya sedikit memiliki peluang untuk mengontrol peristiwa-peristiwa yang akan diselidiki, dan bila mana fokus penelitian terletak pada fenomena masa kini didalam konteks kehidupan nyata.

\section{Ruang Lingkup Penelitian}

Rumusan masalah menjadi acuan peneliti dalam menentukan ruang lingkup penelitian ini. Adanya ruang lingkup penelitian ini sebagai batasan saat dilakukannya penelitian dengan harapan mampu menjawab rumusan masalah yang penulis buat untuk terpenuhinya tujuan penelitian yaitu bagaimana peran produk simpanan dan pembiayaan dalam pemberdayaan ekonomi anggota unit jasa keuangan syariah?

\section{Jenis dan Sumber data}

Adapun data yang diperlukan dalam penelitian ini adalah data primer (utama) dan dan data sekunder (penunjang). Data primer dapat diperoleh melalui wawancara secara langsung terhadap objek terkait. Sedangkan data sekunder dapat diperoleh dengan cara membaca dan mengumpulkan literatur-literatur yang berkaitan dengan topik penelitian.

\section{Unit Analisis}

Dalam unit analisis ini Peneliti menggunakan teknik purposive sampling dalam menentukan informan dari penelitian. Dalam penelitian ini unit analisis adalah anggota unit simpan pinjam dan pembiayaan syariah assakinah surabaya yang mengikuti program pemberdayaan anggota dengan menggunakan produk keuangan yang ditawarkan, yaitu produk simpanan dan produk pembiayaan.

\section{Pengumpulan data}

Langkah-langkah memperoleh data adalah sebagai berikut :

a. Menyelesaikan birokrasi dan surat ijin penelitian pada Fakultas Ekonomi Dan Bisnis Universitas Airlangga.

b. Mendatangi objek penelitian dan melakukan wawancara terhadap informan terkait.

\section{Teknik Analisis Data}

Adapun teknik analisa data yang digunakan adalah teknik penjodohan pola (pattern matching), yaitu logika penjodohan adalah membandingkan pola yang didasarkan atas empiris dengan pola yang diprediksikan (Yin, 2013: 140). Dalam hal ini peneliti melakukan perbandingan antara teori empiris yang terdapat pada bab sebelumnya dan proposisi yang telah dibuat dengan data yang diperoleh dari hasil wawancara terhadap informan yaitu angggota dari Unit 
Bagus S, et al/Jurnal Ekonomi Syariah Teori dan Terapan Vol. 4 No. 8 Agustus 2017: 657-667; PEMBERDAYAAN EKONOMI ANGGOTA KOPERASI JASA KEUANGAN SYARIAH MELALUI PRODUK PEMBIAYAAN DI KOPERASI SIMPAN PINJAM DAN PEMBIAYAAN SYARIAH MUAMALAH BERKAH SEJAHTERA SURABAYA

Simpan Pinjam Dan Pembiayaan

Syariah. Semakin besar persamaan

antara kedua pola tersebut maka semakin menguatkan pula pada validitas internal studi kasus yang bersangkutan.

\section{Hasil dan Pembahasan}

Koperasi simpan pinjam dan pembiayaan syariah Muamalah Berkah Sejahtera dinilai dapat memberikan sumbangsih yang besar pagi para anggotanya, pemberdayaan tersebut dikemas dalam bentuk produk keuangan yaitu produk simpanan dan produk pembiayaan dengan berbagai variasi. Adapun bentuk variasi dari produk simpanan antara lain adalah simpanan, simpanan terencana, deposito .Sedangkan variasi dari produk pembiayaan adalah pembiayaan modal kerja, pembiayaan multijasa, dan pembiayaan multiguna. Variasi-variasi dan model produk tersebut dibuat tentunya dengan tujuan dan manfaat yang berbeda bagi anggota-anggota Koperasi Syariah Muamalah Berkah Sejahtera

Di suatu sisi, motivasi atau upaya mensejahterakan anggota melalui produk-produk keuangan yang ada adalah saling tolong-menolong dalam memenuhi kebutuhan serta bersamasama menjalankan aktivitas ekonomi yang sesuai dengan syariat islam sehingga visi ibadah juga akan terlaksana dengan baik. Adapun hal tersebut sesuai dengan sabda Rasulullah SAW sebagai berikut: Dari Abu Hurairah RA, ia berkata : Rasulullah SAW bersabda, "Barangsiapa meringankan satu kesusahan orang mukmin dari kesusahan-kesusahannya di dunia, maka Allah akan meringankan satu kesusahan dari kesusahankesusahan pada hari giyamat. Barangsiapa memberi kemudahan kepada orang yang dalam kesulitan, Allah akan memberi kemudahan kepadanya di dunia dan di akhirat. Barangsiapa menutup aib orang muslim, maka Allah akan menutup aibnya di dunia dan di akhirat. Dan Allah selalu menolong hamba-Nya selama hamba itu suka menolong saudaranya"(HR. Muslim).

Pemberdayaan ekonomi melalui produk simpanan

1. Pembiayaan Modal Usaha

Terdapat empat orang dari informan yang menggunakan pembiayaan yang diterimanya untuk menambah modal usaha yang dijalani. Dengan pembiayaan tersebut informan merasa dapat meningkatkan usahanya, baik dari segi output maupun laba yang didapatkan, walaupun masih ada beberapa usaha yang mengalami peningkatan yang belum begitu signifikan namun dengan pembiayaan 
Bagus S, et al/Jurnal Ekonomi Syariah Teori dan Terapan Vol. 4 No. 8 Agustus 2017: 657-667; PEMBERDAYAAN EKONOMI ANGGOTA KOPERASI JASA KEUANGAN SYARIAH MELALUI PRODUK PEMBIAYAAN DI KOPERASI SIMPAN PINJAM DAN PEMBIAYAAN SYARIAH MUAMALAH BERKAH SEJAHTERA SURABAYA

tersebut informan sangat merasa terbantu dalam meningkatkan usahanya maupun dalam memperbaiki kondisi perekonomiannya.

2. pembiayaan konsumtif

Dalam pembiayaan konsumtif terdapat dua variasi atau model pembiayaan, yaitu pembiayaan sakinah multiguna dan pembiayaan sakinah multijasa. Pembiayaan sakinah multiguna diperuntukkan bagi anggota dalam memenuhi kebututannya dengan sistem pengadaan barang, sedangkan pembiayaan sakinah multijasa merupakan pembiayaan untuk membantu anggota memenuhi kebutuhannya namun bukan dalam bentuk pengadaan barang, melainkan dalam bentuk jasa.

Selanjutnya, informan yang peneliti temui tidak satupun yang menggunakan poduk multijasa, semua informan menggunakan produk pembiayaan multiguna, rata-rata dari mereka menggunakannya dalam bentuk pengadaan barang yang mereka butuhkan. Dengan demikian atas data yang didapat oleh para informan bahwa unit simpan pinjam dan pembiayaan syariah As-Sakinah berperan dalam pemberdayaan ekonomi anggota salah satunya adalah pemenuhan kebutuhan konsumsi mereka pengadaan barang melalui pembiayaan sakinah mulitiguna.
Penjelasan diatas menunjukkan keberhasilan koperasi simpan pinjam dan pembiayaan syariah Muamalah Berkah Sejahtera surabaya dalam memberdayakan ekonomi anggotanya melalui berbagai inovasi atau modelmodel peroduk keuangan yang ditawarkan. Penjelasan tersebut juga diperkuat oleh informan yang dipilih pihak Koperasi MBS, dalam hal ini peneliti memilih Sekretaris Koperasi Syariah MBS karena dirasa informan ini adalah orang yang mengerti selukbeluk unit yang dipimpinnya secara mendalam. Informan berpendapat bahwa koperasi simpan pinjam dan pembiayaan syariah MBS telah berperan dalam upaya

memberdayakan ekonomi anggota melalui produk pembiayaan yang dirasa dapat memperkuat modal usaha anggota yang nantinya akan meningkatkan produksinya, disisi lain KSPPS MBS juga memberikan pendampingan bagi anggota yang akan memulai usaha baru atau anggota yang telah memiliki usaha yang nantinya KSPPS juga akan membantu dalam memasarkan produk dari usaha anggota.

\section{Simpulan \\ Berdasarkan hasil dari pembahasan sebelumnya dapat disimpulkan bahwa Koperasi Syariah}


Bagus S, et al/Jurnal Ekonomi Syariah Teori dan Terapan Vol. 4 No. 8 Agustus 2017: 657-667; PEMBERDAYAAN EKONOMI ANGGOTA KOPERASI JASA KEUANGAN SYARIAH MELALUI PRODUK PEMBIAYAAN DI KOPERASI SIMPAN PINJAM DAN PEMBIAYAAN SYARIAH MUAMALAH BERKAH SEJAHTERA SURABAYA

Muamalah Berkah Sejahtera berperan dalam pemberdayaan ekonomi anggota melalui produk pembiayaan yang ditawarkan. Produk - produk tersebut berupa pembiayaan dengan berbagai variasi dan model yang tentunya memiliki fungsi dan manfaat yang berbeda antara satu produk dengan produk lainnya. Namun terdapat faktor - faktor internal dan eksternal yang dapat mempengaruhi kesuksesan ataupun kegagalan dalam peran koperasi syariah dan informan sendiri. Dari 5 informan yang dilakukan wawancara, 4 orang diantarannya dapat dikatakan sukses dan berdaya, 1 informan termasuk dalam kategori tetap dan tidak ada peningkatan.

Pemberdayaan melalui produk pembiayaan modal usaha memiliki dampak yang positif bagi usaha yang dimiliki informan yaitu dapat meningkatkan output maupun pendapatan mereka walaupun peningkatannya belum begitu signifikan. Namun dampak yang dirasakan memiliki peran positif bagi anggota, terutama dapat membantu mereka dalam merealisasikan keinginan yang telah direncanakan sebelumnya serta dapat membantu meningkatkan perekonomian mereka sehingga kondisi perekonomian anggota dapat tertata dengan baik.
Secara umum Koperasi Syariah Muamalah Berkah Sejahtera telah berperan dalam mensejahterakan anggotanya melalui program pemberdayaan ekonomi yaitu dengan berbagai model produk pembiayaan yang ditawarkan.

\section{DAFTAR PUSTAKA}

Departemen Pendidikan Dan Kebudayaan. 1993. Kamus Besar Bahasa Indonesia Jakarta: Balai Pustaka.

Departemen Agama Republik Indonesia. 2006. Al-quran Dan Terjemahannya. Jakarta: CV. Pustaka Agung Harapan.

Kartasasmita, Ginandjar. 1996. Pembangunan Untuk rakyat. Memadukan pertumbuhan dan pemerataan. (Online), (www.ginandjar.com, diakses 14 November 2015).

Koperasi Pesantren Hidayatulloh AsSakinah.http://kpphassakinah.com. (Online), diakses pada 7 Januari 2016.

Republik Indonesia. Peraturan Menteri Negara Koperasi dan Usaha Kecil dan Menengah Republik Indonesia Nomor $\quad: 91 / K e p / M . K U K M / I X / 2004$. $2004 . \quad$ (Online), (http://www.depkop.go.id.html, diakses 12 November 2015). 
Bagus S, et al/Jurnal Ekonomi Syariah Teori dan Terapan Vol. 4 No. 8 Agustus 2017: 657-667; PEMBERDAYAAN EKONOMI ANGGOTA KOPERASI JASA KEUANGAN SYARIAH MELALUI PRODUK PEMBIAYAAN DI KOPERASI SIMPAN PINJAM DAN PEMBIAYAAN SYARIAH MUAMALAH BERKAH SEJAHTERA SURABAYA

--------. Menteri Negara Koperasi Dan

Usaha Kecil Dan Menengah. 2007.

Peraturan Nomor: $\quad 35.2$

/Per/M.KUKM/X/2007. Tentang

Pedoman Standar Operasional

Manajemen Koperasi Jasa Keuangan

Syariah Dan Unit Jasa Keuangan

Syariah Koperasi. (online)

www.depkop.go.id, diakses pada 12

November 2015.

- Menteri Negara Koperasi Dan

Usaha Kecil Dan Menengah Republik Indonesia. 2007. Peraturan Nomor: 35.3/Per/M.KUKM/X/2007. Tentang Pedoman Penilaian Kesehatan Koperasi Jasa Keuangan Syariah Dan Unit Jasa Kevangan Syariah Koperasi. Undang-undang Republik Indonesia No. 10 Tahun 1998 tentang Perbankan.

-------. Undang-undang Republik Indonesia No. 10 Tahun 1998 tentang Perbankan. Undang-undang Republik Indonesia No. 10 Tahun 1998 tentang Perbankan.

Santoso. Fiqih. (2008). Concept and Method for Community Empowerment Indonesia, http://appreciativeorganization.word press.com. (Online), diakses pada 16 Januari 2016

Sholihan, H. Asmuni. 2006. Fikih Ekonomi Umar Bin Al-Khattab. Jakarta:

Khaifah.
Solihin, Ahmad Ifham. 2010. Pedoman Umum Lembaga Keuangan Syariah. Jakarta: Kompas gramedia.

------. 2010. Buku Pintar Ekonomi Syariah. Jakarta: Gramedia pustaka utama.

Subagyo, Ahmad. 2015. Kevangan Mikro Syariah. Jakarta: Mitra wacana media.

Sulistiani, Ambar Teguh. 2004. Kemitraan Dan Model-Model Pemberdayaan. Jogjakarta: Gava Media.

Yin, Robert K. 2013. Studi kasus: desain dan metode. Jakarta: Rajawali Press. 